\title{
The Effect of Transformational Leadership Style, Motivation, and Organizational Culture on Organizational Commitments Mediated by Work Satisfaction At Muhammadiyah Malang University
}

\author{
Bambang Widagdo and Kenny Roz \\ University of Muhammadiyah Malang
}

\begin{abstract}
This study purpose was to examine the effect of transformational leadership style, motivation, and organizational culture on organizational commitment mediated by job satisfaction at University of Muhammadiyah Malang. This study collaborates with previous research phenomena of research object. The research object is the University of Muhammadiyah Malang. This research uses a quantitative approach and 114 samples were selected by a purposive sampling method. The results showed that transformational leadership style had no significant effect on organizational commitment, organizational culture had a significant effect on organizational commitment, job satisfaction had a significant effect on organizational commitment, motivation had a significant effect on organizational commitment, transformational leadership style had no significant effect on job satisfaction, transformational leadership style no significant effect on job satisfaction, organizational culture has a significant effect on job satisfaction, motivation has a significant effect on job satisfaction, and job satisfaction can mediate the effect of organizational culture, and motivation on organizational commitment, while leadership style does not significantly affect organizational commitment through job satisfaction.
\end{abstract}

Keywords: transformational leadership style, motivation, organizational culture, job satisfaction, organizational commitment.

DOI: $10.7176 / \mathrm{EJBM} / 12-12-08$

Publication date: April $30^{\text {th }} 2020$

\section{INTRODUCTION}

Employee commitment becomes the benchmark to determine organization success to achieve predetermined goals. Employees with high commitment will support the organization through attitudes to do the job seriously. Kreitner and Kinicki (2011) suggested that organizational commitment is a reflection of an employee / worker to recognize and understanding the organization and is bound by organizational goals. Organizational commitment can also be interpreted as a psychological bond of an employee that characterized by trust and strong acceptance of goals and values of organization, desire to strive to achieve organizational interests (Sopiah, 2008).

Employees with high organizational commitment to their organization are affected by several factors as leadership style, employee motivation, organizational culture, and job satisfaction. Atmojo (2012) found that transformational leadership style has a positive and significant effect on organizational commitment. This research proves that implementation of transformational leadership style in a company creates high organizational commitment to every employee. This is also reinforced by Abouraia and Othman (2017) that high commitment can be achieved by implementation of transformational leadership styles.

Other research explains other factor to affects a person to have high organizational commitment. Mathis and Jackson (2006) explained that motivation developed by Maslow is triggered by how human efforts to fulfil their needs. Maslow's theory explains the hierarchy of needs which is closely related to motivation as physiological, security, social, appreciation, and self-actualization needs.

Organizational commitment can also be affected by organizational culture and job satisfaction. Mochyi (2013) found that organizational culture is a system of values, norms, rules, philosophies, beliefs and behaviours shared to affect work patterns and organizational management patterns. Robbins (2008) found that job satisfaction is a general attitude in every individual towards his work. If people work and are satisfied with what they have done, he will be highly committed to organization or workplace.

Mitic et al. (2016) showed a relationship between the dimensions of organizational culture and dimensions of organizational commitment. Joseph's research (2017) also reinforced the finding that a good organizational culture has a high effect on organizational commitment at universities in Serang City. Ismail and Razak (2016) got other findings that job satisfaction is significantly related to organizational commitment. This study was also strengthened by Daniel and Purwanti (2015), Shaah et al. (2014).

\section{Research purposes}

These study objectives are to examine: (a) the effect of Transformational Leadership Style on organizational commitment, (b) the effect of Organizational Culture on Organizational Commitment, (c) the effect of Job 
Satisfaction on Organizational Commitment. (d) the effect of Transformational Leadership Style on Job Satisfaction. (e) the effect of motivation on job satisfaction, (f) the effect of Motivation on Organizational Commitment, (g) the effect of Organizational Culture on Job Satisfaction. This research also examine the mediation effect as follows (h) the effect of Transformational Leadership Style on Organizational Commitment through Job Satisfaction, (i) the effect of motivation on organizational commitment through job satisfaction, (j) the effect of Organizational Culture on Organizational Commitment through Work Power

\section{LITERATURE REVIEW}

\section{Organizational Commitment}

Kreitner and Kinicki (2011) suggested that organizational commitment is a reflection of employees to recognize and understanding the organization and the goals. Organizational commitment is considered important because this is a work attitude to shows willingness to work hard to achieve the goals / vision of organization and strong desire to continue work in an organization. Robbin (2008) stated that organizational commitment is a situation where an employee takes sides with organizational goals and has a desire to maintain his membership in organization.

Allen and Meyer (1997) explained that organizational commitment is the level a person identifies himself with organization for his involvement in organization. There are 3 components that must be understood. Affective Organizational Commitment (AOC) is an emotional approach from a person / individual in their involvement with organization, so that individuals will feel connected to organization. Continuance Organizational Commitment (COC) is an employee desire to associate with organization. Normative Organizational Commitment (NOC) is a feeling to oblige employee to remain in organization.

\section{Transformational Leadership Style}

Leadership is the ability to affect a group to achieve a specified goal. Leadership involves the deliberate social process by a person to affect others to structure activities and to affects a group or organization. Transformational Leadership Style is a person's ability to inspire other human resources in an organization to achieve something beyond organization plan (Solihin, 2009). Transformational leaders rely more on charisma and authority (referent power) to lead. Tria (2012) found that transformational leadership motivates subordinates to do better than what can be done.

The transformational leadership style emphasizes the symbolic behavior, provides messages of vision and inspiration, nonverbal communication, ideological values, intellectual stimulation of followers by leaders, appearance of self-confidence, and leaders expectations to followers to make self-sacrificing for performance that goes beyond their duty (Kreitner and Kinicki, 2005). Robbin (2008) stated that transformational leadership style has following indicators: (a) Leaders emphasize independence in subordinates, (b) Leaders provide inspiration and motivation to subordinates, (c) Leaders prioritize education as a basis to change thinking, and (d) Leaders involves subordinates in decisions making.

\section{Motivation}

Robbins (2008) defined motivation as a process to explain the intensity, direction, and perseverance of an individual to achieve his goals. Motivation is a series of attitudes and values to effect individuals to achieve specific things in accordance with individual goals (Rivai, 2009). Mathis and Jackson (2006) explained human motivation developed by Maslow that motivation is triggered by how human efforts to meet their needs. Maslow's hierarchy explained the needs consisting of: (a) Physiological, as cloth, food, shelter, and other physical needs, (b) Security, as safety and protection against physical and emotional losses, (c) Social, as love, mutual ownership, good acceptance, friendship, (d) Appreciation, as self-esteem, autonomy, and achievement, and (e) self-actualization, as encouragement to become a person or according to his ambitions which include growth, achieving potential, and fulfilling self-needs.

\section{Job satisfaction}

Job satisfaction is an individual character everyone have different levels of satisfaction according to values, norms believed. Robbins (2008) defined job satisfaction as a general attitude within every individual towards their work. Several studies have suggested that job satisfaction will affect the attitudes and behavior of employees at work, especially behavior that will be reflected in various things, including attendance, moral level, and labour turnover. These will affect their commitment to organization.

Kreitner and Kinicki (2005) found that job satisfaction is "an affective or emotional response to various aspects of work" and explains 5 models of job satisfaction. First is meeting needs, this model explains that satisfaction is determined by characteristics of a job to allow a person to meet the needs. Second is Non-matching, this model explains that power is the result of expectations being fulfilled. Third is Achievement of values, this model explains that satisfaction comes from perspective of a job makes it possible to fulfil important work values 
of individuals. Forth is Equality, this model explains satisfaction is a function of how an individual is treated and considered in workplace. Fifth is Character / genetic, this model explains someone's satisfaction measured by person feeling satisfied with certain work situations and conditions, but some are dissatisfied with other condition.

\section{Organizational culture}

Culture is an important concept to understand society and human groups in long run. Robbin (2008) and Molenaar (2002) suggested that organizational culture theory has full power, it means that organizational culture affects the individual and performance even to work environment. Organizational Culture is the assumptions, basic beliefs, values, norms, rules, attitudes and behavior shared by all members (Luthans, 2006).

Organizational culture has important elements according to theory of Robbins (2008). These elements include: (a) Innovation, level of encouragement to employees to be innovative and dare to take risks, (b) Orientation to details, level of demand for employees to be able to show accuracy, analysis, and attention to detail, (c) Orientation to results, level of demand for management to focus more on results, rather than attention to techniques and processes to achieve these results, (d) orientation towards the individual, level of management decisions in considering the effects of results on individuals in organization, (e) Team orientation, level of work activities set in team, not individually, (f) Aggressiveness, level of demand for people to be aggressive and competitive, and not relaxed, and $(\mathrm{g})$ Stability, level of activity emphasis organization in maintaining a good organizational culture.

\section{Previous Research}

Researchers compose from the previous research by using variables to affect organizational commitment, namely transformational leadership style, motivation, organizational culture, and job satisfaction. Collin Silverthorne (2014) examined the effect of organizational culture, organizational commitment and work satisfaction in Taiwan to found an organizational culture relationship to employee satisfaction and organizational commitment. Olaleka Oluseye et al. In 2014 examined the effects of motivation and job satisfaction to found that intrinsic motivation and extrinsic motivation have a positive and significant effect on job satisfaction both simultaneously or partially.

Ismail and Razak (2016) examined the effect of job satisfaction and organizational commitment to found that job satisfaction has a significant effect on organizational commitment. Achmad Bakir Pasaman et al. (2018) examine the transformational leadership style, job satisfaction and organizational commitment and found eight from 9 hypotheses significantly affect the studied variables. The only one that does not have a significant effect is Transformational Leadership on Employee Job Satisfaction, which needs to be mediated by organizational learning and organizational change. Amir Sohail et al. (2014) examine motivation, job satisfaction and organizational commitment and found a positive and significant relationship between motivation, job satisfaction, and organizational commitment.

\section{Research Conceptual Framework}

Research Framework is shown in figure 1.

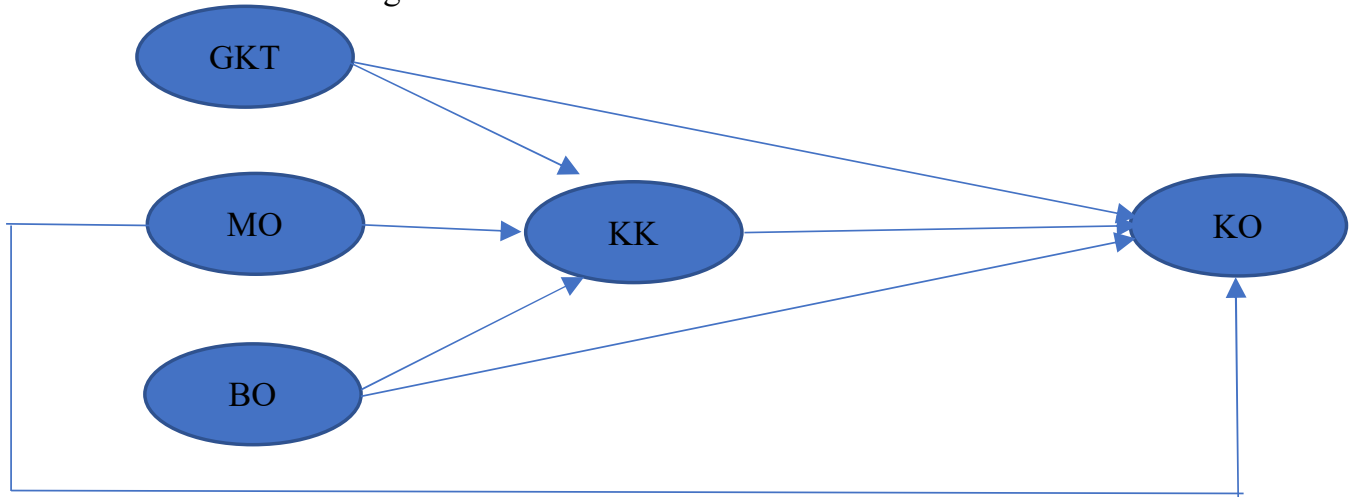

Figure 1. Research Framework

The hypotheses proposed in this study are below.

H1: Transformational Leadership Style has a significant effect on Organizational Commitment.

H2: $\quad$ Organizational Culture has a significant effect on Organizational Commitment.

H3: Job Satisfaction has a significant effect on Organizational Commitment.

H4: Motivation has a significant effect on organizational commitment.

H5: Transformational Leadership Style has a significant effect on Job Satisfaction.

H6: Motivation has a significant effect on Job Satisfaction.

H7: Organizational Culture has a significant effect on Job Satisfaction.

H8: Transformational Leadership Style has a significant effect on Organizational Commitment through Job Satisfaction. 
H9: Motivation has a significant effect on organizational commitment through job satisfaction.

H10: Organizational Culture has a significant effect on Organizational Commitment through Job Satisfaction

\section{RESEARCH METHODOLOGY}

\section{Data Collection Techniques and Data Sources}

Data is collected by questionnaires and distributed via online. The questionnaires use a language that is easily understood by respondents. List of questions have relation to variables items of transformational leadership style, motivation, organizational culture, job satisfaction, and organizational commitment.

\section{Population and Research Samples}

The study population are lecturers who worked at University of Muhammadiyah Malang. The samples are selected by purposive sampling method. Purposive sampling certain conditions or considerations adjusted to research needs. The minimum samples with a variables $\leq 5$ should 100 or above (Hair et al., 2014). This study uses 114 respondents who worked at University of Muhammadiyah Malang.

\section{RESULTS AND DISCUSSION}

Measurement Evaluation Model

Two analyzes can be done, namely outer model and inner model. The steps are conducting validity and reliability tests. To assess validity, internal consistency measurements are used according to reliability of measurement with alpha coefficients, composite reliability, average variance extracted (AVE) for each construct, as shown in table 1.

Table 1. Average Variance Extracted (AVE)

\begin{tabular}{|l|l|}
\hline Variables & AVE \\
\hline Transformational Leadership Style (X1) & 0.756 \\
\hline Motivation (X2) & 0.755 \\
\hline Organizational Culture (X3) & 0.745 \\
\hline Job Satisfaction (Y1) & 0.691 \\
\hline Organizational Commitment (Y2) & 0.812 \\
\hline
\end{tabular}

Source: Primary data, processed in 2019

Table 1 shows the value of AVE in each variable above 0.5 . It can be concluded that the discriminant validity of measurement model is good.

\section{Reliability Test}

The reliability test is shown in table 2 .

Table 2. Reliability Test Results

\begin{tabular}{|l|c|c|}
\hline Variables & Crobach Alpha & Composite Reliability \\
\hline Transformational Leadership Style & 0.925 & 0.892 \\
\hline Motivation & 0.914 & 0.892 \\
\hline Organizational Culture & 0.921 & 0.887 \\
\hline Job Satisfaction & 0.918 & 0.891 \\
\hline Organizational Commitment & 0.928 & 0.881 \\
\hline
\end{tabular}

Source: Primary data, processed in 2019

Table 2 shows the composite reliability above 0.7 . It means that the constructs are reliable.

\section{Structural Model Measurement}

The result of structural model measurement is shown in table 3.

Table 3. Determination Test Result

\begin{tabular}{|l|l|}
\hline \multicolumn{1}{|c|}{ Variable } & \multicolumn{1}{|c|}{$\mathbf{R}^{\mathbf{2}}$} \\
\hline Job Satisfaction & 0.764 \\
\hline Organizational Commitment & 0.587 \\
\hline
\end{tabular}

Source: Primary data, processed in 2019

Table 3 shows coefficient of determination for Job Satisfaction of lecturers at University of Muhammadiyah Malang is affected by Transformational Leadership Style, Organizational Culture and Motivation by 0.764 or by $76.4 \%$ and remaining $23.6 \%$ is affected by other variables outside this study. Organizational Commitment of Malang Muhammadiyah University lecturers are affected by Transformational Leadership Style, Organizational Culture, and Job Satisfaction by 0.587 or $58.7 \%$ and remaining $42.3 \%$ is affected by other variables. 


\section{Hypothesis test}

The hypotheses test is shown in figure 2 and table 4.

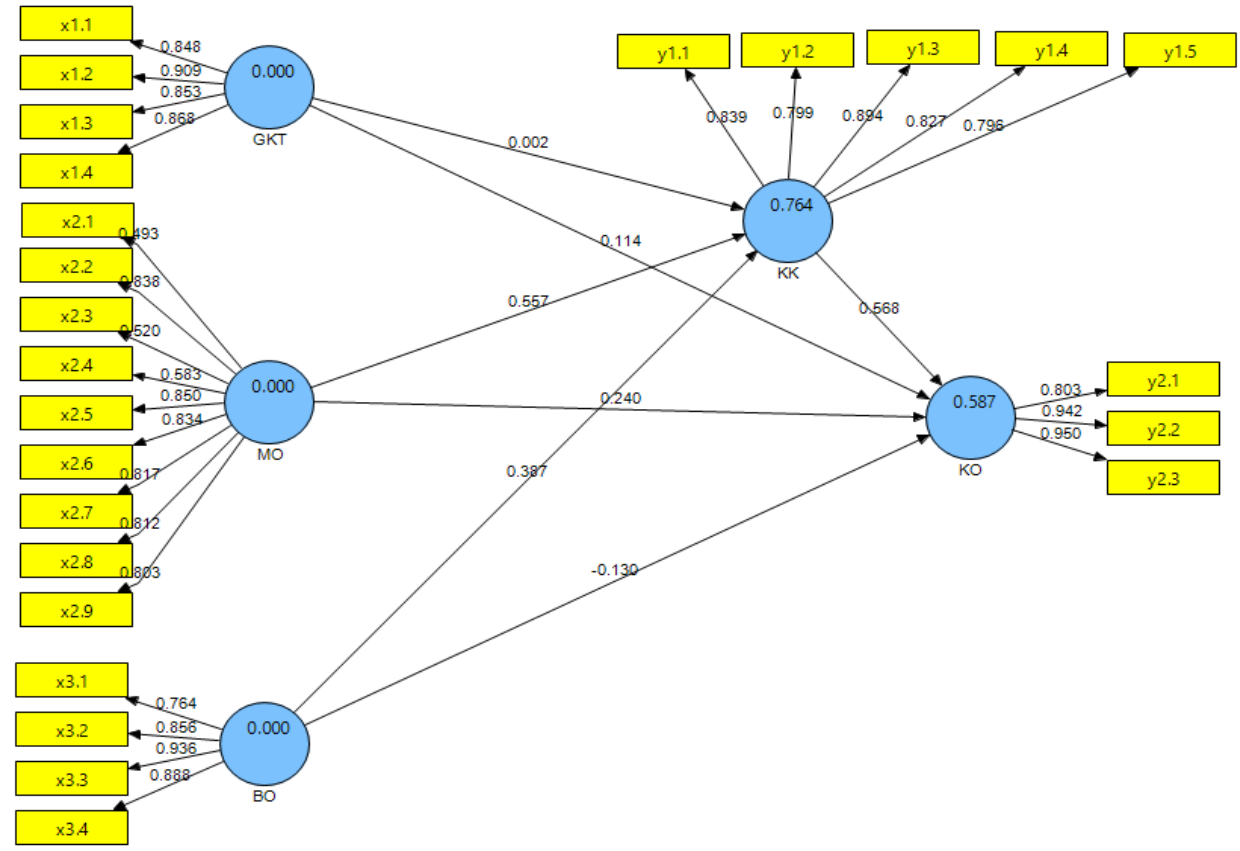

Figure 2. Path coefficient of PLS Analysis Results

Table 4. Hypotheses Testing Results

\begin{tabular}{|c|c|c|c|}
\hline Effects & $\begin{array}{l}\text { Path } \\
\text { Coefficient }\end{array}$ & $\begin{array}{l}\text { Statistical } \\
\text { T }\end{array}$ & Significance \\
\hline \multicolumn{4}{|l|}{ Direct Effect } \\
\hline Organizational Culture $\rightarrow$ Job Satisfaction & 0.387 & 4.54 & 0.000 \\
\hline Organizational Culture $\rightarrow$ Organizational Commitment & 0.367 & 4.21 & 0.000 \\
\hline Transformational LS $\rightarrow$ Job Satisfaction 0.002 & 0.002 & 0.017 & 0.966 \\
\hline Transformational LS $\rightarrow$ Organizational Commitment & 0.114 & 1.830 & 1.171 \\
\hline Job Satisfaction $\rightarrow$ Organizational Commitment & 0.567 & 3.369 & 0.000 \\
\hline Motivation $\rightarrow$ Job Satisfaction & 0.557 & 5.331 & 0.000 \\
\hline Motivation $\rightarrow$ Organizational Commitment & 0.556 & 4.697 & 0.000 \\
\hline \multicolumn{4}{|l|}{ Indirect Effect } \\
\hline $\begin{array}{l}\text { Organizational Culture } \rightarrow \text { Job Satisfaction } \rightarrow \text { Organizational } \\
\text { Commitment }\end{array}$ & 0.220 & 3.632 & 0.000 \\
\hline $\begin{array}{l}\text { Transformational LS } \rightarrow \text { Job Satisfaction } \rightarrow \text { Organizational } \\
\text { Commitment }\end{array}$ & 0.001 & 0.042 & 0.967 \\
\hline $\begin{array}{l}\text { Motivation } \\
\text { Commitment }\end{array} \rightarrow$ Job $\quad$ Satisfaction $\rightarrow \quad$ Organizational & 0.316 & 3.861 & 0.000 \\
\hline
\end{tabular}

Source: Primary data, processed in 2019

Testing the Effect of Transformational Leadership Styles on Job Satisfaction

Table 4 shows transformational leadership style (X1) has a positive effect on Job Satisfaction (Y1) at path coefficient $(0.114)$ but insignificant at $t$-statistic value $(1,830)$ smaller than the t value table $(1.96)$ with an error tolerance (alpha) of 5\%. This shows that transformational leadership style of leader has not been able to affect subordinates (lecturers) to commit to their organization. Therefore, hypothesis 1 is rejected.

Testing the Effect of Organizational Culture on Organizational Commitment

Table 4 shows transformational leadership style (X1) has a positive effect on organizational commitment (Y2) at path coefficient of 0.367 and significant at t-statistic (4.21) is larger than the table (1.96) with an error tolerance (alpha) of 5\%. The direction of a positive relationship shows that better the organizational culture will improve someone commitment to organization. Therefore, Hypothesis 2 is accepted. 


\section{Testing the Effect of Job Satisfaction on Organizational Commitment}

Table 4 shows the job Satisfaction (Y1) has a positive effect on Organizational Commitment (Y2) at path coefficient (0.567) and t-statistic (3.369) is larger than t table (1.96) with an error tolerance (alpha) of 5\%. The direction of a positive relationship shows that higher level of job satisfaction of lecturers will increase the organizational commitment. Therefore, Hypothesis 3 is accepted.

\section{Testing the Effect of Motivation on Organizational Commitment}

Table 4 shows the Motivation has a positive effect on Organizational Commitment (Y2) at path coefficient of 0.556 and significant at t-statistic value $(0.369)$ is larger than the value of $t$ table (1.96) with an error tolerance (alpha) of 5\%. The positive direction shows that better work motivation of lecturers will increase the organizational commitment. Therefore, Hypothesis 4 is accepted

\section{Testing the Effect of Transformational Leadership Styles on Job Satisfaction}

Table 4 shows the Transformational Leadership Style (X1) has a positive effect on Job Satisfaction (Y2) at path coefficient of 114 and insignificant at t-statistic value (1.830) is smaller than the t value table (1.96) with an error tolerance (alpha) of 5\%. This shows that transformational leadership style cannot provide a sense of satisfaction to lecturers. Therefore, Hypothesis 5 is rejected.

\section{Testing the Effect of Motivation on Job Satisfaction}

Table 4 shows the Motivation (X2) has a positive effect on Job Satisfaction (Y1) at path coefficient (0.557) and significant at $t$ statistic value (5.331) larger than $t$ table (1.96) with an error tolerance (alpha) of 5\%. This means that good work motivation increase work satisfaction of lectures. Therefore, Hypothesis 6 is accepted.

\section{Testing the Effect of Organizational Culture on Job Satisfaction}

Table 4 shows the organizational culture (X2) has a positive effect on job satisfaction (Y1) at path coefficient (0.387) and significant at t-statistic (4.74) larger than t table (1.96) with an error tolerance (alpha) of 5\%. The positive direction shows that better organizational culture in organization can increase job satisfaction of lectures. Therefore, Hypothesis 7 is accepted.

\section{Testing the Effect of Transformational Leadership Styles on Organizational Commitment through Job Satisfaction}

Table 4 shows that transformational leadership style (X1) has a positive effect on organizational commitment (Y2) through job satisfaction (Y1). The t statistics show $(0.042)<\mathrm{t}$ table $(1.96)$ or $<\mathrm{p}$ value 0.05 . It means that indirectly the transformational leadership style cannot affect organizational commitment through job satisfaction. The job satisfaction as mediation variable cannot guarantee the job satisfaction when a leader applies a transformational leadership style to make employees to commit to organization. Therefore, Hypothesis 8 is rejected.

\section{Testing the Effect of Motivation on Organizational Commitment through Job Satisfaction}

Table 4 shows the direct effect of motivation (X2) on organizational commitment (Y2) through job satisfaction (Y1). The $t$ statistic $(1.96)<t$ table of $(3.861)$ at value $<0.05$. It shows the effect of work motivation on organizational commitment through job satisfaction is directly proportional. This is interpreted as better / higher work motivation will increase satisfaction to improve organizational commitment. Therefore, Hypothesis 9 is accepted.

Testing the Effect of Organizational Culture on Organizational Commitment through Job Satisfaction Table 4 shows the direct effect of organizational culture (X3) on organizational commitment (Y2) through job satisfaction (Y1). The $t$ statistic $(1.96)<t$ table $(3.362)$ at $p$ value $<0.05$. It shows the effect of organizational culture on organizational commitment through job satisfaction is directly proportional. This can be interpreted that better organizational culture in an organization will increase job satisfaction to increase employees commitment to organization. Therefore, Hypothesis 10 is accepted.

\section{Conclusions and recommendations}

Based on results of study, data analysis and discussion that has been done, the conclusion can be stated below.

1. Transformational leadership style at University of Muhammadiyah Malang is good. Leadership style has the ability to inspire employees (lecturers) to achieve what is planned, but it does not have a significant effect on organizational commitment. This is because applying a collegial leadership style refers to a leadership system that involves the parties concerned in decisions making or policies through the mechanisms adopted and promote togetherness.

2. Organizational culture at University of Muhammadiyah Malang is good. Good organizational culture is 
clearly felt by employees (lecturers) in completing the work. Organizational culture has a significant effect on organizational commitment at University of Muhammadiyah Malang. The better organizational culture at University of Muhammadiyah Malang can improve the commitment of employees (lecturers) to organization.

3. Job satisfaction at University of Muhammadiyah Malang is high. Satisfaction felt by employees (lecturers) resulted in reluctance to leave this institution. Job satisfaction of employees (lecturers) at University of Muhammadiyah Malang has a significant effect on organizational commitment. The higher job satisfaction of employees (lecturers) at University of Muhammadiyah Malang can increase the commitment of employees (lecturers) to organization.

4. Transformational leadership style at University of Muhammadiyah Malang is good. Leadership style has the ability to inspire employees (lecturers) to achieve what is planned, but it does not have a significant effect on job satisfaction. This is due to several decisions taken by a leader that are considered inappropriate for some employees (lecturers).

5. The motivation of employees (lecturers) of University of Muhammadiyah Malang is high. An employee (lecturer) who works based on high motivation will affect the quality of work done. The motivation of employees (lecturers) of University of Muhammadiyah Malang has a significant effect on job satisfaction. The higher the motivation of employees (lecturers) at University of Muhammadiyah Malang will increase the job satisfaction (lecturers).

6. Motivation of employees (lecturers) of University of Muhammadiyah Malang is high. The Lectures work with high motivation to keep working done through hard skills and soft skills owned. University of Muhammadiyah Malang has employees (lecturers) who are highly motivated to remain loyal and loyal to company, because they feel the agencies have given what they want. Motivation has a significant effect on organizational commitment. The higher the motivation can increase the commitment of employees (lecturers) of University of Muhammadiyah Malang.

7. Organizational Culture affects the Organizational Commitment through job satisfaction. High job satisfaction mediates the effect of organizational culture in Muhammadiyah University on organizational commitment.

8. Transformational leadership style at University of Muhammadiyah Malang is good. However, transformational leadership style does not significantly affect organizational commitment through job satisfaction. Employees (lecturers) feel not satisfied with transformational leadership style at University of Muhammadiyah Malang. This makes employees do not loyal and commit to University of Muhammadiyah Malang.

9. Motivation of employees (lecturers) of University of Muhammadiyah Malang is high. Motivation has a significant effect on organizational commitment through job satisfaction. The satisfaction felt by employees (lecturers) of University of Muhammadiyah Malang to work gives a good effect to remain committed to institution. It can be said that higher the motivation of employees (lecturers) increases the commitment to institution through high job satisfaction.

10. Organizational culture in University of Muhammadiyah Malang is good. Organizational culture has a significant effect on organizational commitment through job satisfaction. Implementing a good organizational culture makes the employees (lecturers) of University of Muhammadiyah Malang committed to institution. It can be concluded that better organizational culture at University of Muhammadiyah Malang will increase the commitment to institution through high job satisfaction.

This research has some limitation the authors give suggestions below.

1. Muhammadiyah University of Malang continues to apply the existing organizational culture. The current organizational culture is empirically proven to have a significant effect on motivation and job satisfaction of employees (lecturers) to remain committed to institution.

2. Implementing transformational leadership style does not have a significant effect on motivation, and job satisfaction of employees (lecturers) of University of Muhammadiyah Malang. It is recommended to apply other leadership styles such as collegial leadership style to affect an employee (lecturer) to remain committed to institution.

\section{REFERENCES}

Abouraia, M. K. dan Othman, S. M. (2017). Transformational Leadership, Job Satisfaction, Organizational Commitment, and Turnover Intentions: The Direct Effects among Bank Representatives. American Journal of Industrial and Business Management, 2017, 7, 404-423. International Reasearch Journal of Business Studies.

Ali, A., Bin, L. Z., Piang, H. J., \& Ali, Z. (2016). The Impact of Motivation on the Employee Performance and Job Satisfaction in IT Park (Software House) Sector of Peshawar, Pakistan. International Journal of Academic Research in Business and Social Sciences, 6(9), Pages 297-310. https://doi.org/10.6007/IJARBSS/v6-i9/2311

Al-Madi, F. N., Assal, H., \& Shrafat, F. (2017). The Impact of Employee Motivation on Organizational Commitment. European Journal of Business and Management, 12. 
Atmojo, Marnis. (2012). The Influence of Transformational Leadership on Job Satisfaction, Organizational Commitment, and Employee Performance.

Cooper, dan P. S. Schindler. 2006. Metode Riset Bisnis (Budijanto, D. Djunaedi, D. Sihombing \& Penerjemah, Trans. 9 ed.). Jakarta: PT Media Global Edukasi.

Daniel, F. dan Purwanti, A. (2015). THE IMPACT OF ORGANIZATIONAL CULTURE AND JOB SATISFACTION TO ORGANIZATIONAL COMMITMENT AND EMPLOYEES JOB PERFORMANCE (An Empirical Study at A University in Tangerang).

Dlamini, N. N. N. (2017). The impact of transformational leadership style on organisational commitment in the hospitality industry. Tourism and Leisure, 6, 21.

Ghozali, I. 2013. Model Persamaan Struktural Konsep \& Aplikasi Amos 21.0 (Edisi tujuh ed.). Semarang: Badan Penerbit Universitas Dipenogoro.

Habib, S., Aslam, S., Hussain, A., Yasmeen, S., \& Ibrahim, M. (2014). The Impact of Organizational Culture on Job Satisfaction, Employess Commitment and Turn over Intention. Advances in Economics and Business, 8.

Kreitner, R., dan A. Kinicki. 2005. Perilaku Organisasi. 5 ed. Jakarta: Salemba Empat.

Hadian, D. (2017). The Relationship Organizational Culture and Organizational Commitment on Public Service Quality; Perspective Local Government in Bandung, Indonesia. 7(1), 8.

Handoko, T.H. 2011. Manajemen, Edisi Kedua, Yogyakarta : BPFE - YOGYAKARTA

Ismail, A., \& Razak, M. R. A. (2016). EFFECT OF JOB SATISFACTION ON ORGANIZATIONAL COMMITMENT. (1), 16.

Long, C. S., Yusof, W. M. M., Kowang, T. O., \& Heng, L. H. (2014). The Impact of Transformational Leadership Style on Job Satisfaction. 9.

Luthans, F. 2006. Perilaku Organisasi. Edisi 10 ed. Yogyakarta: Penerbit Andi.

Mathis, R.L. dan John H Jackson. 2006. Manajemen Sumber Daya Manusia .

Mitic, S., Vukonjanski, J., Terek, E., Gligorovic, B., \& Zoric, K. (2016). Organizational culture and organizational commitment: Serbian case. Journal of Engineering Management and Competitiveness, 6(1), $21-27$. https://doi.org/10.5937/jemc1601021M

Mochyi, Achmad. 2013. Teori dan Perilaku Organisasi. UMM Press. Malang

Molenaar, Keith, 2002, Corpoarte Culture, a Study of Firm With Outstanding Consideration Safety . Prosesional Safety pp 18-27

Niguse, G., \& Hirpesa, T. (2018). The effects of organizational culture on organizational commitment: The mediating role of job satisfaction, in case of Oromia forest and wild life enterprise. International Journal of Commerce and Management Research, 4(3), 01-05.

Ogunnaike, O. O., Akinbola, O. A., \& Ojo, O. A. (2014). Effect of Motivation on Job Satisfaction of Selected Sales Representatives. Journal of Educational and Social Research. https://doi.org/10.5901/jesr.2014.v4n1p197

Omar, W. A. W. (2013). Transformational Leadership Style and Job Satisfaction Relationship: A Study of Structural Equation Modeling (SEM). International Journal of Academic Research in Business and Social Sciences, 3(2), 20.

Orabi, T. G. A. (2016). The Impact of Transformational Leadership Style on Organizational Performance: Evidence from Jordan. International Journal of Human Resource Studies, 6(2), 89. https://doi.org/10.5296/ijhrs.v6i2.9427

Rivai H. Veithzal dan Sagala, Ella Jauvani. (2009). Manajemen Sumber Daya manusia untuk Perusahaan Dari Teori ke Praktik Edisi Kedua. Jakarta : Rajawali Pers.

Rizal, M., Idrus, M.S., Djumahir, \& Mintarti, R. 2014. Effect of Compensation on Motivation, Organizational Commitment and Employee Performance (Studies at Local Revenue Management in Kendari City). International Journal of Business and Management Invention, Vol. 3, No. 2, pp: 64-79.

Robbins, S. P., dan T. A. Judge. 2008. Organization Behavior Edisi 12. Jakarta: Salemba.

Salleh, S. M., Zahari, A. S. M., Said, N. S. M., \& Ali, S. R. O. (2016). The Influence of Work Motivation on Organizational Commitment in the Workplace. 5.

Sanei, N. S., Islamic Azad University, Neyshabur, Iran, Poursalimi, M., \& Ferdowsi University of Mashhad, Mashhad, Iran. (2018). Mediating role of job satisfaction in the relationship between motivation, perceived support, training and perceived commitment. Journal of Research and Health, 8(1), 3-11. https://doi.org/10.29252/acadpub.jrh.8.1.3

Shaah, F.T.,Idress, F., Imam, A.,Khan, T.A, Mariyam, A. (2014) Impact of Job Satisfaction on Organizational Commitment in IT Sector Employees of Pakistan.

Silverthorne, C. (2004). The impact of organizational culture and person-organization fit on organizational commitment and job satisfaction in Taiwan. Leadership \& Organization Development Journal, 25(7), 592599. https://doi.org/10.1108/01437730410561477

Sinani, J. (2016). Motivational Factors and Organisational Commitment of the Educational Institution's Employee. 
Journal of Educational and Social Research. https://doi.org/10.5901/jesr.2016.v6n1p89

Solihin, I. 2009. Pengantar Manajemen. Jakarta: Penerbit Erlangga.

Sopiah. (2008). Perilaku Organisasi, Yogyakarta: Andi Offset.

Sugiyono. 2008. Metode Penelitian Kualitatif dan Kuantitatif. Jakarta: Alfabeta.

Tria, M. 2012. Pengaruh Kepemimpinan Transformasional Dan Kompensasi Terhadap Kinerja Karyawan PT. PLN (PERSERO) UPJ SEMARANG. Jurnal Administrasi Bisnis 1.

Tsai, Y. (2011). Relationship between Organizational Culture, Leadership Behavior and Job Satisfaction. BMC Health Services Research, 11(1), 98. https://doi.org/10.1186/1472-6963-11-98

Yusuf, F.A., (2017) The Impact of Organizational Culture, Leadership, Job Satisfaction and Trust towards Lecture's Organizational Commitment of the Private Universities in Serang Regency Indonesia. International Journal of Human Resource Studies. Vol. 07. No. 01 